\title{
A Novel Prototype and Simulation Model for Real Time Solid Waste Bin Monitoring System
}

(Pembangunan Prototaip dan Model Simulasi Baharu untuk Sistem Pemantauan Masa Sebenar Tong Sisa Pepejal)

Md. Abdulla Al Mamun*, M. A. Hannan \& Aini Hussain

ABSTRACT

This research deals with an exclusive solution to monitor the solid waste bin condition on real time. The system architecture is designed using wireless sensor networks. A set of carefully chosen sensors are used to measure the status of the bins and ZigBee and GPRS are used as communication technologies. The physical architecture of the system contains three levels such as smart bins for the measurement and transmission of bin status, gateways for storing and forwarding bin data to server and control station for storing and analyzing the data. After the framework design, a simulation is performed using Castalia to ensure the feasibility and accuracy of the system. The simulation is performed for ten bins and taking ten samples from each bin where a fill level threshold of 15 is considered. The simulation result shows that, the proposed system would be able to automate the solid waste monitoring process that helps to optimize waste collection route.

Keywords: Wireless Sensor Network; ZigBee-Pro; GSM/GPRS; OMNET++

ABSTRAK

Kajian ini berkaitan dengan satu penyelesaian yang eksklusif untuk memantau keadaan tong sisa pepejal pada masa nyata. Seni bina sistem direka menggunakan rangkaian pengesan tanpa wayar. Satu set sensor yang dipilih dengan teliti telah digunakan untuk mengukur status tong sisa pepejal dan ZigBee dan GPRS digunakan sebagai teknologi komunikasi. Seni bina fizikal sistem itu mengandungi tiga peringkat seperti tong pintar untuk mengukur dan penghantaran status tong sisa pepejal, gerbang untuk menyimpan dan menghantar data tong kepada pelayan dan stesen kawalan untuk menyimpan dan menganalisis data. Selepas reka bentuk rangka kerja, simulasi dilakukan dengan menggunakan Castalia untuk memastikan kebolehlaksanaan dan ketepatan sistem. Simulasi ini dilakukan untuk sepuluh tong dan mengambil sepuluh sampel dari setiap tong di mana nilai ambang tahap 15 dipertimbangkan. Keputusan simulasi menunjukkan bahawa, sistem yang dicadangkan akan dapat mengautomasikan proses pemantauan sisa pepejal yang membantu mengoptimumkan laluan kutipan sisa.

Kata kunci: Rangkaian Pengesan Tanpa Wayar; ZigBee-Pro; GSM/GPRS; OMNET++

\section{INTRODUCTION}

It is anticipated that the amount of solid waste will increase near 1.8 million tons per day by the year 2025 due to the excessive use of non-renewable resources (Hoornweg \& Bhada-Tata 2012). In the solid waste management process, waste collection and transport have become a considerable issue due to their impact on social health by emitting pollutant gas along with traffic and noise. Unusual use of vehicles for collecting waste expends more fuel which in turn produces a substantial amount of greenhouse gas (GhG). The number of collection increases when the partially fill up bins are collected. So it is very much needed to optimize the collection process by knowing the accurate information about a bin in advance (Faccio et al. 2011).

Large number of researches has been done on different aspect of solid waste generation, monitoring and its management. Some researchers emphasized on different types of economical, technical and administrative challenges related to municipal solid waste management in developing countries (Henry et al. 2006, Yamamoto 2008). Several researches have been performed related to solid waste generation from various sectors like households, industries, construction sites and many more (Pek \& Jamal 2011, Shekdar 2009). A number of researchers discussed about Radio Frequency Identification (RFID), General Packet Radio Service (GPRS), Geographic Information Systems (GIS), Geographic Positioning System (GPS), routing model and waste collection with bin monitoring application for environmental quality consideration (Hannan et al. 2011, Arebey et al. 2010, Rada et al. 2010). A small number of works have been done to develop real time bin monitoring system (Faccio et al. 2011, Rovetta et al. 2009). However, the developed systems have some limitations like the use of GSM/GPRS in every bin caused a large increase in operating cost, a reduction of nominal bin capacity about $20 \%$ etc. Only one researcher considers wireless sensor network for monitoring the bin status (Longhi et al. 2012) with a huge 
limitation of geographical coverage and also consider only single parameter for the bin status. In this work, a real time solid waste bin monitoring system architecture has been proposed which is based on wireless sensor network (WSN) technology that can overcome the above limitations and can reduce operation costs while covering large area. A simulation model is also introduced to simulate the system.

\section{SYSTEM ARCHITECTURE}

Physically the system is designed that consisting three main parts from the bin to the control station namely 1) smart bin, 2) gateway and 3) control station as shown in Figure 1.

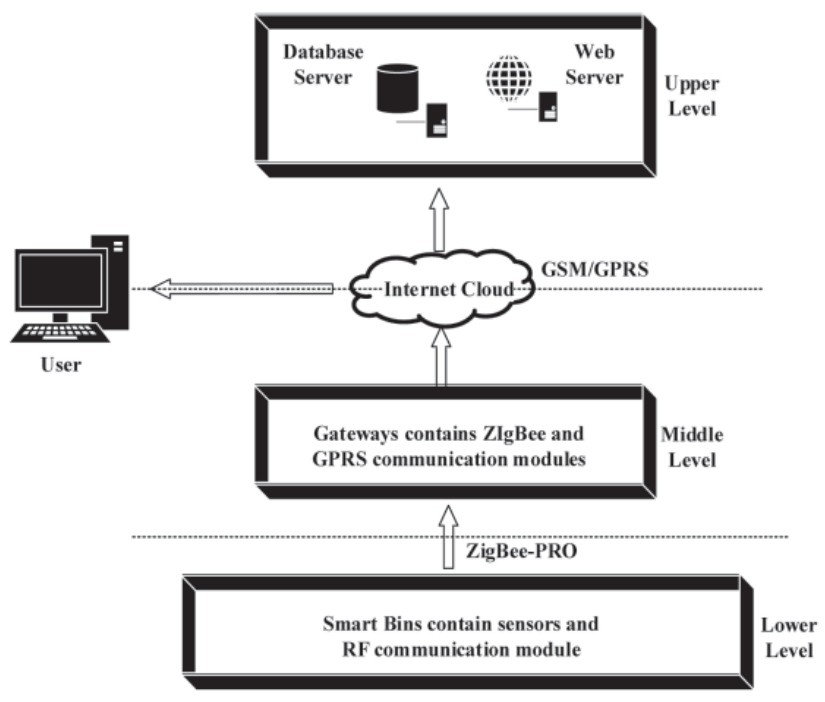

FIGURE 1. Architecture of the real time bin monitoring system

SMART BIN

The lower level contains smart bins which are composed of a set of sensory elements. The chosen sensors are divided into two groups. The first group is mounted underneath the bin cover and the other is in the bottom of the bin. The former group consists of an accelerometer, a hall effect, an ultrasound, a temperature and a humidity sensor and the later group consists of the load cell sensor. The accelerometer sensor keeps track on the bin cover and react when the cover is opened from close state or vice versa. The hall effect sensor monitors whether the bin cover is closed properly or not to perceive if the bin is overloaded or not. The ultrasound sensor measures the waste fill level inside the bin. The load cell sensor measures the weight of the waste inside the bin. The temperature and humidity sensor measure the ambient temperature and humidity of the bin for the purpose of monitoring the performances of other sensors. The data measured by the sensors are sent to the gateway through ZigBee-PRO communication module which is based of IEEE 802.15.4 and developed by ZigBee alliance. IEEE 802.15.4 standard is designed for reliable, cost-effective, low-power wireless networking and defines the physical layer (PHY) and medium access control sublayer (MAC) specifications. The ZigBee alliance optimized the feature set for ZIgBee PRO to provide low power consumption and to support large networks. The smart bin uses waspmote and smart metering PRO sensor board from libelium as the sensor node.

\section{GATEWAY}

The gateway receives the data sent by the lower level. It then parses the data and stores to its local database. If the GPRS connectivity is available, it sends connection request with the server to the control station through GPRS communication. After the establishment of connection, the gateway sends the data to the control station. When GPRS in unavailable, the gateway sends an SMS containing the data to a specific cell number. The designed system considers Meshlium from libelium as the gateway which can act as a multiprotocol router.

\section{CONTROL STATION}

The control station resides in the upper level that contains servers. A daemon process in the server is responsible to make connection with the gateway when a connection request is arrived. It then receives the data sent by the gateway and stores it into a central database storage. The central server hosts a set of web applications that facilitate user friendly interface to monitor the updated bin status.

\section{SIMULATION MODEL}

OMNET++ based Castalia simulator is used to validate and evaluated the working principles of the proposed system. Castalia is open source simulator and has a realistic and modular environment for radio and wireless channel. The simulation model is shown in Figure 2(a) and (b) (Boilis 2009). Figure 2(a) shows the model for a composite node module. Each node consists of application radio, routing, MAC, sensor manager, mobility and resource manager modules. The simulation result is significantly affected by the defined protocols and parameters for each module. The application is simple module that defines new algorithms based on specific application. It implements different features and functionality for the precise application for which the simulation will be performed.

The radio module is a sub module of the communication composite modules that takes care about the radio. It offers to adopt many features of a radio that are mostly same as real low-power radio usually used in wireless sensor networking application. The MAC module is a sub module of the communication composite modules which implements the Medium Access Control protocol for Castalia.

Many important behaviors of the nodes depend on this module. The routing module is also a sub module of the communication composite modules which offers the implementation of routing algorithms. For this application, this module receives less care compared to other modules 

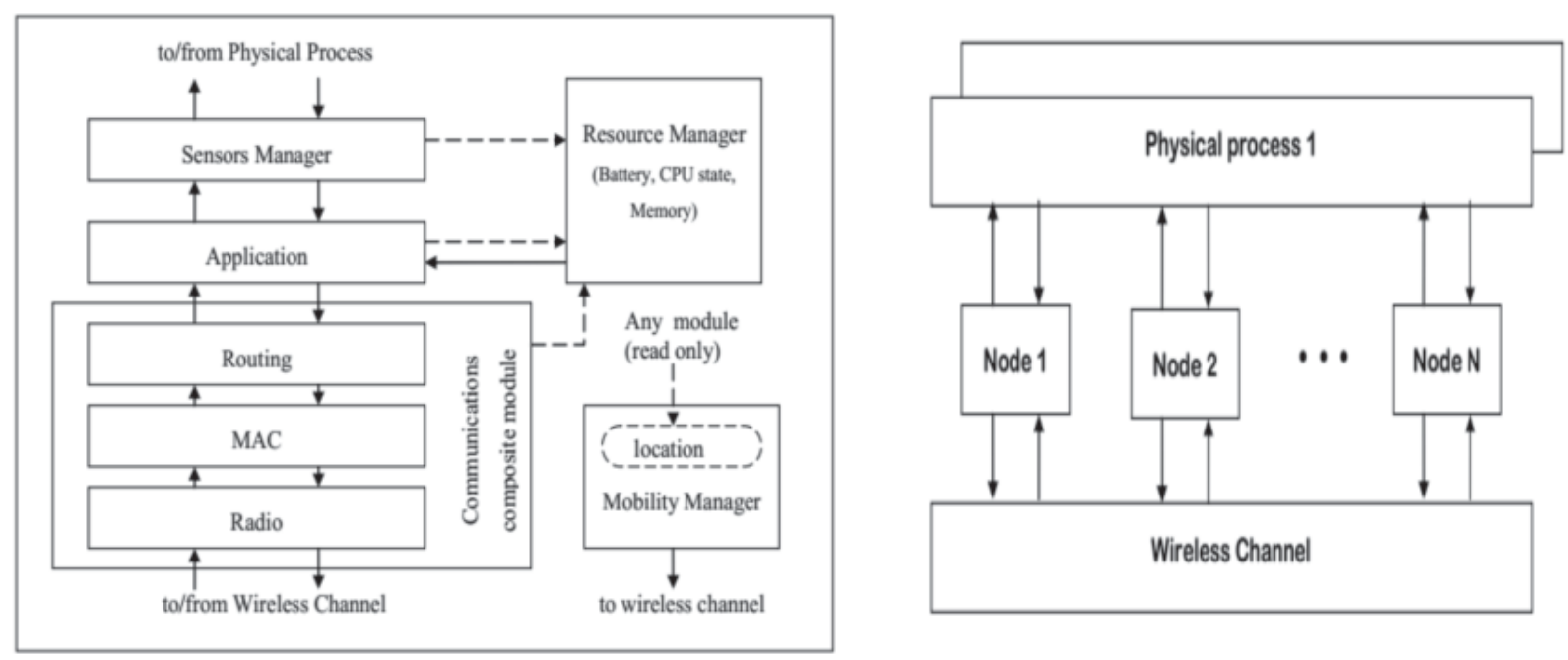

FIGURE 2. (a) Composite node model, (b) Network model

as star topology is used to design the network. The sensor manager keeps track on number and types of sensing devices used. It also specifies different characteristics of the sensing devices like power consumption, resolution, sensitivity, noise and device bias, and connects the sensing devices to corresponding physical process.

The mobility module takes care about the movement of mobile nodes through space. It maintains location state which other modules can access. This module also informs the position of a node to the wireless channel from time to time for efficiency reasons. The resource manager module monitors the energy consumed by the node based on their clock drift along with the baseline power consumption. Usually the radio and sensor manager modules send messages to resource manager module to inform about power draw and the resource manager calculates the energy consumption for each operation. Figure 2(b) shows the sensor network model where each node is a node composite module as in Figure 2(a). The physical process provides facility to obtain sensing data close to real life sensing. This module considers noise or bias of sensing devices to estimate the data instead of producing the data only by random number generation. To model the wireless channel, Castalia captures various important real life features such as average path loss, temporal variation, node mobility.

Using this simulator, a sensor network application is created for the validation of the bin status monitoring phenomenon. New application module is defined in the composite node module. The flowchart of the application module is shown in Figure 3. The developed application module initializes the threshold value for bin fill level and time for interruption to request sensor data. By using this value the application triggers the physical process of the sensor nodes after a random time.

After receiving the request the PHYsical process returns with sensor data sample through sensor manager. The

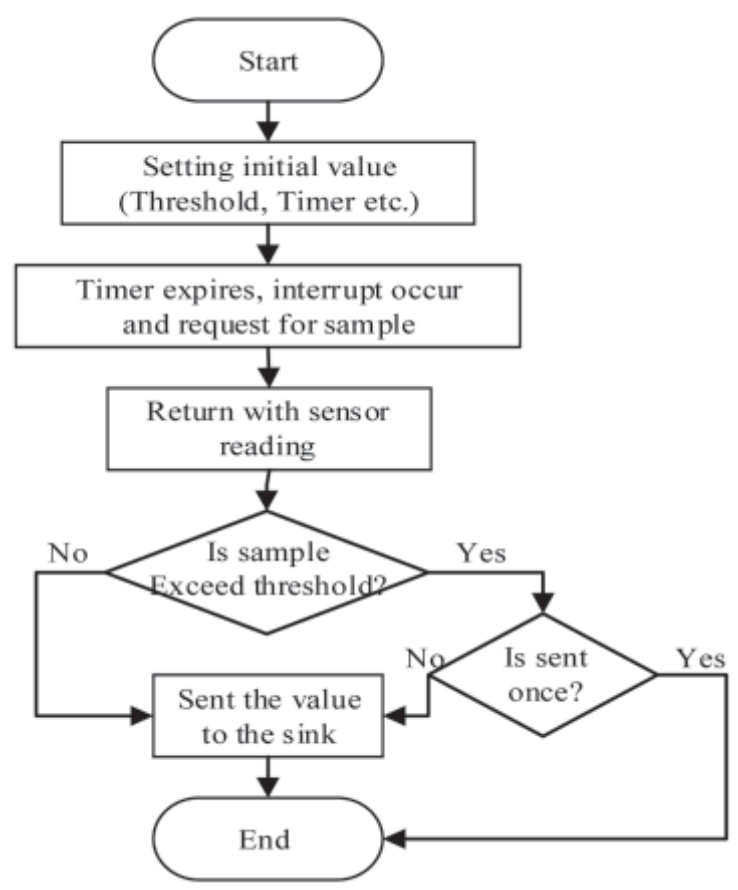

FIGURE 3. Flow chart of application simple module

sample is feed into the node's internal processor and some comparison performed. Based on the result of the comparison the sampled data is send to the network layer which places the data to the radio for the purpose to send the data to the sink node. Therefore, the responsibility of sensor nodes is to inform the status of the bin to a sink node. Star topology is used for the simulation. The sink node is placed in the center and the other nodes are positioned in an area using a random uniform distribution. 


\section{RESULT AND DISCUSSION}

For the simulation a physical process is created that represents the sensor reading. The physical process contains 10 samples for the ultrasonic sensor that measure waste filling level inside the bin. In a $500 \times 500$ meter area 10 bins are considered. The simulation result is shown in Figure 4 considering a level threshold of 15 . The $\mathrm{X}$ axis represents the sample for each bin which represent as node. Each line denotes the change in bin filling level sample by sample shown in $\mathrm{Y}$ axis. In each sample the filling level is increased and shows a rising trend in the graph. However, for a bin, when the filling level reached in the threshold value of 15 then the filling level value is dropped for the next sample of the corresponding bin. This means that, when the bin is fill up by waste, the system would be updated its information in the control station and the personnel responsible for collection have collected and emptied the bin.

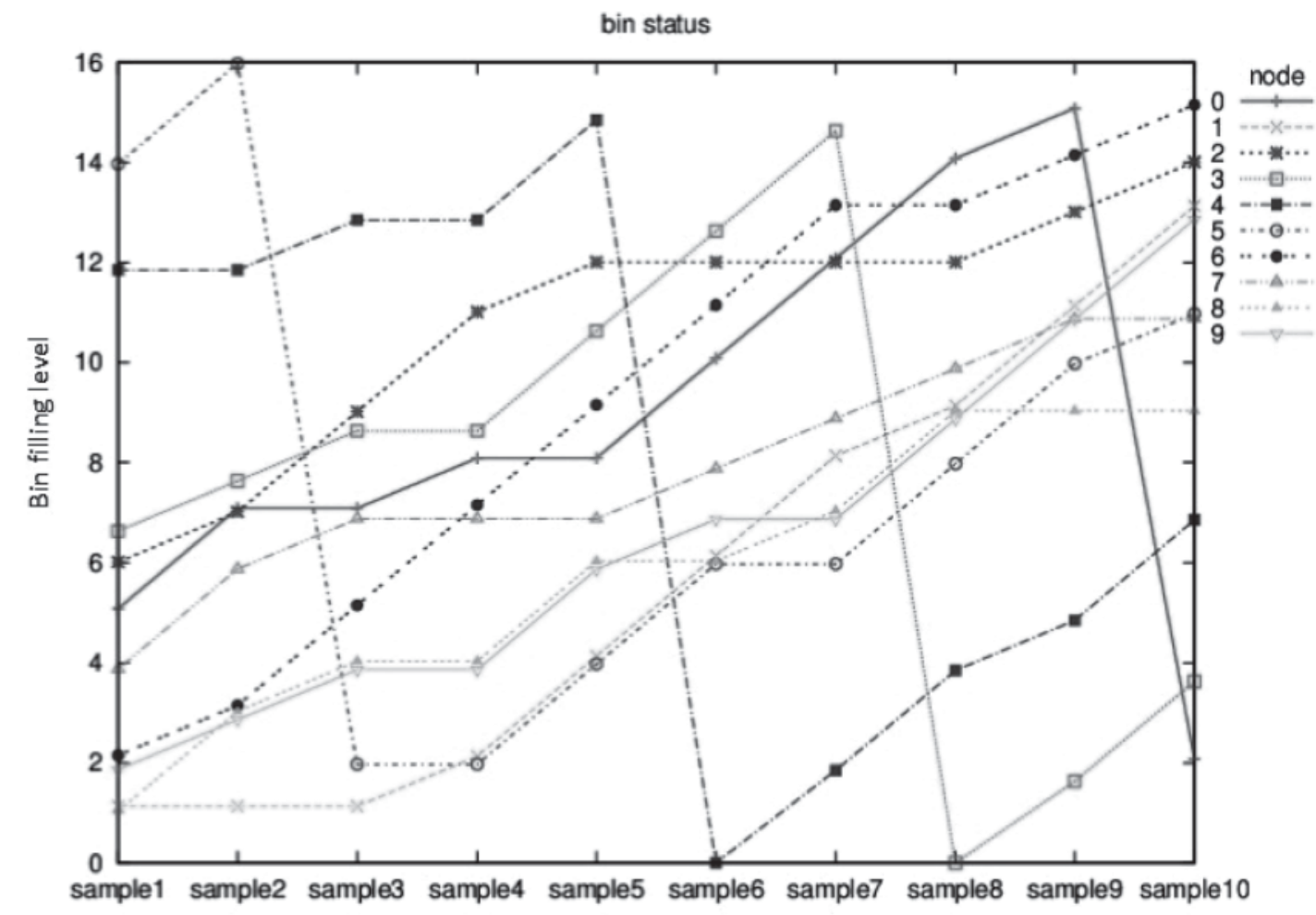

FIGURE 4. Filling level of 10 bins in 10 samples

CONCLUSION

This paper proposes a novel architecture for real time solid waste bin status monitoring system and validates it through simulation. The designed architecture presents an advance system that can collect and monitor bin information as soon as someone throws waste inside a bin. The functions of the system are to acquire various data about bin condition, make some initial measurement on bin level and then send the data to the control station through the gateway. The developed application module with other modules of Castalia simulator simulates the functioning of the proposed prototype. The proposed system can be used by the waste management authority to help for optimization of waste collection routes by using the real time fill level data and thus the system is able to reduce pollutant emissions and operation costs.
ACKNOWLEDGEMENT

The authors acknowledge the financial support from grants LRGS/TD/2011/UKM/ICT/04/01 and PRGS/1/12/TK02/ $\mathrm{UKM} / 02 / 2$.

REFERENCES

Arebey, M., Hannan, M. A, Basri, H. \& Begum, R. A. 2010. Solid waste monitoring system integration based on RFID, GPS and camera. In Intelligent and Advanced Systems (ICIAS). International Conference on Intelligent and Advanced Systems (ICIAS), Kuala Lumpur: 1-5.

Boulis, A. 2009. Castalia, A Simulator for Wireless Sensor Networks and Body Area Networks. Australia: National ICT Australia Ltd, Australia. 
Faccio, M., Persona, A. \& Zanin, G, 2011. Waste collection multi objective model with real time traceability data. Waste Management 31(12): 2391-2405.

Hannan, M. A., Arebey, M., Begum, R. A. \& Basri, H. 2011. Radio Frequency Identification (RFID) and communication technologies for solid waste bin and truck monitoring system. Waste Management 31(12): 2406-2413.

Henry, R. K., Yongsheng, Z. \& Jun, D. 2006. Municipal solid waste management challenges in developing countriesKenyan case study. Waste Management 26(1): 92-100.

Hoornweg, D. \& Bhada-Tata, P. 2012. What a Waste - A Global Review of Solid Waste Management. World Bank, U.S.A.

Longhi, S., Marzioni, D., Alidori, E., Di Buo, G., Prist, P., Grisostomi, M. \& Pirro, M. 2012. Solid Waste Management Architecture Using Wireless Sensor Network Technology. 5th International Conference on New Technologies Mobility and Security (NTMS).

Pek, C.-K. \& Jamal, O. 2011. A choice experiment analysis for solid waste disposal option: A case study in Malaysia. Journal of Environmental Management 92(11): 29933001.

Rada, E., Grigoriu, M., Ragazzi, M. \& Fedrizzi, P. 2010. Web oriented technologies and equipments for MSW collection. In Proceedings of the International Conference on Risk Management, Assessment and Mitigation-RIMA 10(201): 150-153.
Rovetta, A., Xiumin, F., Vicentini, F., Minghua, Z., Giusti, A. \& Qichang, H. 2009. Early detection and evaluation of waste through sensorized containers for a collection monitoring application. Waste Management.

Shekdar, A.V. 2009. Sustainable solid waste management: an integrated approach for Asian countries. Waste Management. 29(4): 1438-1448.

Yamamoto, K. 2008. Municipal Solid Waste Management for a Sustainable Society. Urban Environmental Management and Technology. Springer: 91-105.

Md. Abdulla Al Mamun*, M.A. Hannan \& Aini Hussain Department of Electrical, Electronic and Systems

Engineering

Faculty of Engineering \& Built Environment

Universiti Kebangsaan Malaysia

43600 UKM Bangi, Selangor D.E.

Malaysia

*Corresponding author; email: md.abdulla@siswa.ukm. edu.my

Recieved Date: 21 ${ }^{\text {st }}$ April 2014

Accepted Date: $6^{\text {th }}$ August 2014 
